\title{
KONSTRIBUSI PAKAN DENGAN FORMULASI AMPAS TAHU PADA PEMBESARAN \\ IKAN LELE SANGKURIANG TERHADAP PENDAPATAN PEMBUDIDAYA DI DESA CANDISARI KECAMATAN SAMBENG KABUPATEN LAMONGAN
}

\author{
Angky Soedrijanto dan Wulan Sari
}

\author{
Fakultas Perikanan Universitas Islam Lamongan \\ Jl. Veteran No. 53 A Lamongan
}

\begin{abstract}
ABSTRAK
Usaha perikanan khususnya budidaya air tawar/payau sekarang tidak lagi dijadikan sebagai usaha sampingan, tetapi banyak masyarakat menjadikan usaha ini sebagai usaha pokok. Usaha budidaya ikan lele merupakan usaha yang mudah dijalankan, dalam merencanakan bisnis budidaya ikan lele. Jenis ikan lele yang kami budidaya adalah jenis ikan lele sangkuriang. Salah satu untuk menunjang hasil produk perikanan penggunaan pakan alternatif dengan formulasi fermentasi ampas tahu dapat menguragi biaya produksi. Metode yang digunakan untuk penentuan sampel lokasi yaitu purposive sampling (kesengaan), penelitian ini sumber datanya didasarkan atas ciri atau sifat tertentu yang dipandang mempunyai sangkut-paut yang erat dengan ciri atau sifat populasi yang sudah diketahui sebelumnya. Dalam pengambilan sampel ini ada 2 jenis sampel, yang mana sampel pertama adalah kolam yang menggunakan pakan alternatif dengan jumlah 6 kolam (A, B, C, D, E, F), dan kolam kedua adalah kolam yang menggunakan pakan pelet dengan jumlah 4 kolam (A, B, C, D). Metode yang digunakan dalam pengambilan kedua sampel adalah random sampling. Penentuan sampel dilakukan secara random/acak. Pada sampel kolam yang pertama menggunakan sampel kolam A sedangkan pada sampel kolam kedua menggunakan sampel kolam B. masing masing sampel sengaja diambil satu sampel kolam karena kateristiknya homogen, sehingga satu sampel dalam masing - masing kolam sudah mewakili jumlah populasi yang ada. Analisa data hasil menggunakan rumus pendapatan, yang mana biaya penerimaan dikurangi biaya total. pendapatan budidaya pembesaran ikan lele menggunakan pakan formulasi fermentasi ampas tahu selama satu tahun dengan tiga siklus adalah Rp. 8.026.000 dan pendapatan menggunakan pakan pellet selama satu tahun dengan dua siklus adalah Rp. 1.530.000. dengan perbandingan $8: 1$, sehingga dapat memberikan konstribusi yang sangat besar terhadap pendapatan.
\end{abstract}

Key words : Pakan alternative formulasi fermentasi ampas tahu, Analisis pendapatan

\section{PENDAHULUAN}

Usaha perikanan khususnya budidaya air tawar/payau sekarang tidak lagi dijadikan sebagai usaha sampingan, tetapi banyak masyarakat menjadikan usaha ini sebagai usaha pokok. Usaha perikanan darat sebagai salah satu sumber penghasilan petani ikan memegang peranan penting dalam kegiatan ekspor. Produksi perikanan darat dengan areal dan potensi yang ada memungkinkan untuk ditingkatkan, yaitu dengan cara memperbaiki kombinasi faktor-faktor produksi dan pembaharuan teknologi. Sektor perikanan darat memperlihatkan prospek dengan pengembangan yang cukup besar baik dari sumber dan potensi maupun identifikasi usahanya (Mimit Primyastanto, 2011).

Usaha budidaya ikan lele merupakan usaha yang mudah dijalankan, dalam merencanakan bisnis budidaya ikan lele. Jenis ikan lele yang kami budidaya adalah jenis ikan lele sangkuriang. Jenis lele sangkuriang adalah ikan budidaya air tawar yang sangat populer. Lele disukai konsumen karena berdaging lunak, sedikit tulang, tidak berduri, dan murah. Dari sisi budidaya, lele relatif tidak memerlukan banyak perawatan dan memiliki masa tunggu panen yang singkat.

Lele termasuk hewan omnivora yang cukup rakus juga bersifat kanibal sehingga akan membutuhkan cukup banyak pakan agar sifat kanibalnya tidak muncul, akibatnnya ongkos produksi juga meningkat. Untuk menyiasati hal tersebut, dibutuhkan pakan alternatif yang terjangkau namun memiliki cukup protein guna perkembangan lele dan mengurangi sifat kanibalismenya. Banyak cara yang telah dilakukan untuk mengurangi biaya pakan, diantarannya penggunaan pakan dengan formulasi fermentasi ampas tahu sebagai pakan alternatif. Menurut penilitian terbaru, pakan ini dapat menyamakan pertumbuhan ikan sekitar $80 \%$. Hal ini bertujuan untuk mengurangi tingkat kanibalisme pada ikan lele. Pemberian pakan formulasi fermentasi ampas tahu merupakan pakan pokok dalam budidaya, 
sedangkan untuk pakan tambahan digunakan pakan buatan pabrik.

Pembuatan pakan formulasi fermentasi ampas tahu ini, juga terdapat bahan tambahan, seperti tepung ikan, tepung agung, bungkil kedelai, dedak halus, bungkil kelapa, polard, dan bungkil kacang. Bahan-bahan tersebut juga memiliki kandugan protein yang tinggi, sehingga sangat baik untuk merangsang pertumbuhan ikan.

Tujuaan penelitian ini adalah Untuk mengetahui konstribusi pakan dengan formulasi fermentasi ampas tahu pada pembesaran ikan lele sangkuriang terhadap pendapatan pembudidaya di Desa Candisari Kecamatan Sambeng Kabupaten Lamongan.

Hipotesis penelitiaan ini adalah berdasarkan latar belakang dan rumusan masalah tersebut diatas, maka dapat diambil suatu hipotesis "Diduga bahan baku pembuatan pakan formulasi fermentasi ampas tahu mudah didapatkan, serta dapat mengurangi biaya produksi dan menambah pendapatan pembudidaya, dibandingkan dengan menggunakan pakan pelet, pendapatan relatif sedikit dan cenderung mengalami kerugian.

\section{MATERI DAN METODE PENELITIAN Metode Pengambilan Sampel}

Metode yang digunakan untuk menentukan lokasi yaitu purposive sampling, atas tujuan dasar tujuan tertentu purposive sampling dapat diartikan pengambilan sampel berdasarkan kesengajaan. Penelitian ini sumber datanya didasarkan atas ciri atau sifat tertentu yang dipandang mempunyai sangkut-paut yang erat dengan ciri atau sifat populasi yang sudah diketahui sebelumnya.

Dalam pengambilan sampel ini ada 2 jenis sampel, yang mana sampel pertama adalah kolam yang menggunakan pakan formulasi fermentasi ampas tahu dengan jumlah 6 kolam (A, B, C, D, E, F), dan kolam kedua adalah kolam yang menggunakan pakan pelet dengan jumlah 4 kolam (A, B, C, D ). Metode yang digunakan dalam pengambilan kedua sampel adalah random sampling. Metode random sampling adalah metode pengambilan sampel secara random atau acak.

\section{Teknik Pengumpulan Data}

Data primer adalah data yang diperoleh langsung dari responden (objek penelitian) (Ardiyansa, 2010). Pengumpulan data primer dilakukan dengan cara observasi, wawancara, partisipasi aktif dan dokumentasi.
Data sekunder adalah data yang telah diperoleh melalui data yang diteliti dan dikumpulkan oleh pihak lain yang berkaitan dengan permasalahan penelitian. Data sekunder diperoleh melalui, studi kepustakaan (Ardiyansa, 2010).

\section{Analisis Data}

Analisis data kuantitatif dilakukan untuk mengetahui pendapatan budidaya ikan lele menggunakan pakan alternatif dan menggunakan pakan pelet. Kemudian hasil dari pengolahan ini diinterprestasikan secara deskriptif untuk menggambarkan tentang kelayakan pengembangan usaha. Analisis yang digunakan yaitu analisa pendapatan

Seringkali ditemui banyak orang yang susah membedakan pendapatan dan keuntungan terutama dari kalangan petani. Banyak dari petani yang menyamakan pendapatan dengan keuntungan yang diperoleh dari berusahatani, terutama petani-petani kecil. Padahal pendapatan dan keuntungan adalah dua hal yang berbeda. Dalam usahatani pendapatan adalah total penerimaan setelah dikurangi dengan biaya produksi (biaya yang dibayarkan) sedangkan keuntungan adalah total penerimaan setelah dikurangi biaya produksi (biaya yang dibayarkan) dan biaya yang diperhitungkan.

Keuntungan usaha atau pendapatan bersih adalah besarnya penerimaan setelah dikurangi dengan biaya yang dikeluarkan untuk produksi baik tetap maupun tidak tetap. Perhitungan keuntungan dapat dilakukan dengan rumus sebagai berikut :

$$
\pi=\mathrm{TR}-\mathrm{TC}
$$

Keterangan :

$$
\begin{array}{cl}
\pi & : \text { Keuntungan (Rp / tahun) } \\
\mathrm{TR} & : \text { Total Revenue (penerimaan total) } \mathrm{Rp} / \\
& \text { tahun } \\
\mathrm{TC} & : \text { Total Cost (biaya total) } \mathrm{Rp} / \mathrm{tahun} \\
\mathrm{VC} & : \text { Variable Cost (biaya variabel) } \mathrm{Rp} / \text { tahun } \\
\mathrm{FC} & : \text { Fixed Cost (biaya tetap) } \mathrm{Rp} / \text { tahun }
\end{array}
$$

\section{HASIL DAN PEMBAHASAN}

\section{Hasil Penelitian}

Pedoman Teknis Budidaya Pembesaran Ikan Lele Sangkuriang

Kegiatan budidaya pembesaran ikan lele meliputi: (1) persiapan kolam (2) penebaran benih ikan (3) pemberian pakan (4) pengelolaan kualitas air (5) pemberantasan hama dan penyakit (6) pemanenan 


\section{Analisis Usaha Budidaya}

\section{Biaya Tetap}

Biaya tetap adalah biaya yang harus dikeluarkan walaupun produksi yang diperoleh besar ataupun kecil. Biaya tetap dalam kegiatan usaha budidaya ikan lele dengan menggunakan pakan dengan formulasi fermentasi ampas tahu sebagai pakan alternatif dan pakan pelet adalah biaya penyusutan dan biaya sewa.

Table 15. Rincian Biaya Tetap Selama 1 tahun (3 dan 2 siklus) Budidaya Ikan Lele dengan Pakan Formulasi Fermentasi Ampas Tahu dan Pakan Pelet

\begin{tabular}{|c|c|c|c|}
\hline $\begin{array}{c}\text { Komponen } \\
\text { Biaya }\end{array}$ & $\begin{array}{c}\text { Biaya } \\
\text { Penyusutan } \\
\text { Peralatan }\end{array}$ & $\begin{array}{c}\text { Biaya } \\
\text { Sewa } \\
\text { Lahan }\end{array}$ & $\begin{array}{c}\text { Jumlah } \\
\text { Biaya }\end{array}$ \\
\hline $\begin{array}{c}\text { Kolam A } \\
\text { Panen 1 } \\
\text { Panen 2 } \\
\text { Panen 3 }\end{array}$ & $1,335.000$ & 500.000 & $1,335.000$ \\
\hline \multicolumn{3}{|c|}{ Total } & $\mathbf{1 . 8 3 5 . 0 0 0}$ \\
\hline $\begin{array}{c}\text { Kolam B } \\
\text { Panen 1 } \\
\text { Panen 2 }\end{array}$ & $1,335.000$ & 500.000 & $1,335.000$ \\
\hline \multicolumn{4}{|c|}{ Total } \\
\hline
\end{tabular}

Sumber: Data Primer, Tahun 2016

\section{Biaya Variabel}

Biaya variabel atau biaya tidak tetap merupakan biaya yang besar kecilnya dipengaruhi oleh produksi yang diperoleh. Biaya variabel pada penelitian ini meliputi biaya benih, listrik, BBM, biaya pakan dan tenaga kerja.

Tabel 16. Komponen Biaya Variabel Selama 1

Tahun (3 dan 2 siklus) Budidaya Ikan Lele dengan Pakan Formulasi Fermentasi Ampas

Tahu dan Paka Pelet.

\begin{tabular}{|c|c|c|c|c|c|c|}
\hline $\begin{array}{c}\text { Komp. } \\
\text { Biaya }\end{array}$ & Benih & $\begin{array}{c}\text { Listri } \\
\mathbf{k}\end{array}$ & BBM & Pakan & $\begin{array}{c}\text { Tenaga } \\
\text { Kerja }\end{array}$ & $\begin{array}{c}\text { Jumlah } \\
\text { Biaya }\end{array}$ \\
\hline Kolam A & 1.875 .000 & 90.000 & 135.000 & 8.970 .000 & 3.015 .000 & $\mathbf{1 4 . 0 8 5 . 0 0 0}$ \\
\hline Kolam B & 1.200 .000 & 60.000 & 90.000 & 8.137 .500 & 2.110 .000 & $\mathbf{1 1 . 5 9 7 . 5 0 0}$ \\
\hline
\end{tabular}

Sumber: Data Primer, Tahun 2016

Dari tabel diatas dapat kita lihat komponen biaya variabel yang dipakai dalam proses produksi, untuk menggetahui perhitungan dari masing masing komponen dapat dilihat pada lampiran.

\section{Biaya Total}

Biaya total merupakan keseluruhan biaya yang dikeluarkn dalam suatu produksi atau usaha meliputi biaya tetap dan biaya veriabel. Keseluruhan komponen biaya total budidaya ikan lele dengan pakan alternatif dari formulasi fermentasi ampas tahu dan dengan pakan pelet dapat dilihat pada table 17.

Table 17. Biaya Total Budidaya Ikan Lele Selama 1 Tahun (3 dan 2 siklus) dengan Pakan Formulasi Fermentasi Limbah Ampas Tahu dan Pakan Pelet

\begin{tabular}{|c|c|c|c|}
\hline $\begin{array}{c}\text { Jenis } \\
\text { Biaya }\end{array}$ & $\begin{array}{c}\text { Biaya } \\
\text { Tetap }\end{array}$ & $\begin{array}{c}\text { Biaya } \\
\text { Variabel }\end{array}$ & Jumlah \\
\hline $\begin{array}{c}\text { Kolam } \\
\mathrm{A}\end{array}$ & 1.835 .000 & 14.085 .000 & $\mathbf{1 5 . 9 2 0 . 0 0 0}$ \\
\hline $\begin{array}{c}\text { Kolam } \\
\text { B }\end{array}$ & 1.835 .000 & 11.597 .500 & $\mathbf{1 3 . 4 3 2 . 5 0 0}$ \\
\hline
\end{tabular}

\section{Penerimaan}

Penerimaan usaha merupakan produksi yang diterima dari usaha budidaya lele dengan pakan formulasi fermentasi ampas tahu dan dengan pakan pelet. Penerimaan hasil usaha budidaya lele pada kolam yang dimiliki Bapak Humam lebih tinggi pendapatan pada kolam menggunakan pakan formulasi fermentasi ampas tahu, selain menggurangi biaya produksi, pakan formulasi fermentasi ampas tahu dapat tiga kali panen dalam setahunnya, sedangkan kolam yang menggunakan pakan pelet hanya dua kali anen dalan setahunnya. Sehingga pada kolam yang menggunakan pakan formulasi fermentasi ampas tahu dapat menambah hasil pedapatan budidaya ikan lele sangkuriang.

Tabel 18. Biaya Penerimaan dari Total Penjualan Selama 1 Tahun (3 dan 2 siklus) dengan Pakan Formulasi Fermentasi Limbah Ampas Tahu dan Pakan Pelet .

\begin{tabular}{|c|c|c|c|}
\hline $\begin{array}{l}\text { Komponen } \\
\text { Penerimaan }\end{array}$ & $\begin{array}{c}\text { Volume } \\
\text { Produksi }\end{array}$ & $\begin{array}{c}\text { Harga } \\
\text { Jual }\end{array}$ & $\begin{array}{c}\text { Penerimaa } \\
\text { an }\end{array}$ \\
\hline \multicolumn{4}{|l|}{ Kolam A } \\
\hline Panen 1 & 451.5 & 16.000 & 7.224 .000 \\
\hline Panen 2 & 468 & 17.500 & 8.190 .000 \\
\hline Panen 3 & 474 & 18.000 & 8.532 .000 \\
\hline Total & 1.393 .5 & & 23.946 .000 \\
\hline \multicolumn{4}{|l|}{ Kolam B } \\
\hline Panen 1 & 442 & 16.000 & 7.120 .000 \\
\hline Panen 2 & 451 & 17.500 & 7.892 .500 \\
\hline Total & 893 & & 15.012 .500 \\
\hline
\end{tabular}

Data terolah, 2016

\section{Pendapatan}

Pendapatan usaha budidaya ikan lele dengan pakan alternatf dari formulasi fermentasi ampas tahu dan dengan pakan pelet merupakan selisih dari 
jumlah keseluruhan penerimaan dengan biaya yang telah dikeluarkan. Analisi pendapatan atas biaya usaha dibagi menjadi dua, yaitu pendapatan atas biaya tunai dan pendapatan atas biaya total. Informasi analisis pendapatan usaha budidaya ikan lele dengan pakan formulasi fermentasi ampas tahu dan pakan pelet terdapat pada table 19 .

Tabel 19. Pendapatan atas Biaya Tetap dan Pendapatan Biaya Total Selama 1 Tahun (3 dan 2 siklus) dengan Pakan Formulasi Fermentasi Limbah Ampas Tahu dan Pakan Pelet.

\begin{tabular}{|c|c|c|c|c|}
\hline No & $\begin{array}{c}\text { Kolam } \\
\text { Ikan } \\
\text { Lele }\end{array}$ & Penerimaan & Biaya & Pendapatan \\
\hline 1 & $\begin{array}{c}\text { Kolam } \\
\text { A }\end{array}$ & 23.946 .000 & 15.920 .000 & $\mathbf{8 . 0 2 6 . 0 0 0}$ \\
\hline 2 & $\begin{array}{c}\text { Kolam } \\
\text { B }\end{array}$ & 15.012 .500 & 13.432 .500 & $\mathbf{1 . 5 8 0 . 0 0 0}$ \\
\hline \multicolumn{2}{|l}{} \\
\hline
\end{tabular}

Dari tabel diatas dapat dilihat untuk pendapatan pada kolam A yaitu Rp. 8.026.000 dan untuk pendapatan kolam B yaitu Rp. 1.530.000. Dapat dilihat pula selisih penggunaan pakan formulasi fermentasi ampas tahu memperoleh pendapatan yang tinggi dibandingkan dengan menggunakan pakan pelet, sehingga pakan alternatif dapat menjadi pengganti pakan pelet, selain dapat menggurangi biaya produksi, pakan alternatif juga dapat menambah pendapatan pembudidaya.

\section{KESIMPULAN}

Berdasarkan penelitian yang telah dilakukan, dapat diambil kesimpulan bahwa pendapatan budidaya pembesaran ikan lele dengan menggunakan pakan formulasi ffermentasi ampas tahu memiliki pendapatan yang lebih besar dibanding dengan menggunakan pakan pelet, dengan perbandingan $8: 1$. sehingga dapat memberikan konstribusi yang sangat besar terhadap pendapatan pembudidaya ikan lele di wilayah Desa Candisari Kecamatan Sambeng Kabupaten Lamongan.

\section{DAFTAR PUSTAKA}

Soekartawi, 2011 Analisa Usaha Tani. Cetakan Pertama, Universitas Brawijaya. Malang.

Mimit Primyastanto, 2011. Fasibility Study Usaha Perikanan. Universitas Brawijaya. Malang.

Moch. Syambas Basahudin \& Usni Arie, 2014. Pembesaran Lele Sangkuriang Secara Cepat. Penerbt Swadaya. Jakarta.
Yuli yana, 2014. Manfaat Ikan Lele untuk Kesehatan diakses pada tanggal $13 \mathrm{Mei}$ 2016 pukul 13.21 WIB dari http://www.fatsecret.co.id

Chyrun, 2013. Panduan Lengkap Budidaya Lele Sangkuriang diakses tanggal 13 Mei 2016 pukul $\quad 14.00 \quad$ WIB dari http://chyrun.com/panduan-lengkapbudidaya-lele-sangkuriang/

Lutfi ahmad, 2015. Budidaya Ikan Lele Lengkap Pembenihan diakses pada tanggal $15 \mathrm{Mei}$ 2016 pukul 17.00 WIB dari http://lufilahmad.blogspot.com

Rangga, 2010. Biaya Cost Pendapatan Revenue diakses pada tanggal 16 Mei 2016 pukul $09.00 \quad$ Wib dari https://ranggablack89.wordpress.com/2010 /06/07/biaya cost pendapatan revenue dan struktur pasar dalam sistem perekonomian/

Anna Kartika, 2012. Analisis Finansial Usaha Budidaya diakses pada tanggal 20 Mei 2016 pukul 10.15 wib dari http://diploma.ipb.ac.id

Siti Kholifah, 2012. Jurnal Agribisnis dan Agrowisata diakses pada tanggal $20 \mathrm{Mei}$ 2016 pukul 12.10 WIB dari http:// www. academia jurnal.co.id

Nur laila, 2012 . Analisa Pendapatan Usaha Tani diakses pada tanggal 25 Mei 2016 pukul 14.20 WIB dari http:// www academia Analisa Pendapatan

Sugiyono, 2013. Metode penelitian

Ikhlas Hasan, 2013.Pendapatan Usaha Tani diakses pada tanggal 25 Mei 2016 pukul 16.05 WIB dari http:///www usahatani.com.

Ken Suratiyah, 2015. Ilmu Usaha Tani. Penebar Swadaya. Bandung. 